\title{
Die verband tussen die teenwoordigheid van die visparasiet Lamproglena clariae op die skerptandbaber (Clarias gariepinus) en die waterkwaliteit en metaalkonsentrasies in die Vaalrivier, Suid-Afrika
}

Outeurs:

Marilie Esterhuyze,

A Avenant-Oldewage

Affiliasie:

Departement Dierkunde,

Universiteit van

Johannesburg

Posbus 524, Auckland Park,

2006

Korresponderende outeur: MM Esterhuyze

E-pos: emarilie@yahoo.com

Hoe om hierdie artikel aan te haal:

Marilie Esterhuyze,

A Avenant-Oldewage,

Die verband tussen die

teenwoordigheid van die

visparasiet Lamproglena

clariae op die skerptand-

baber (Clarias gariepinus)

en die waterkwaliteit en

metaalkonsentrasies in

die Vaalrivier, Suid-Afrika,

Suid-Afrikaanse Tydskrif

vir Natuurwetenskap en

Tegnologie 38(1) (2019).

https://doi.org/10.36303/

SATNT.2019.38.1.767

Kopiereg:

(C) 2019. Authors

Licensee: Die Suid-

Afrikaanse Akademie vir

Wetenskap en Kuns.

Hierdie werk is onder

die Creative Commons

Attribution License

gelisensieer.
The presence of the fish parasite Lamproglena clariae infecting the African sharptooth catfish (Clarias gariepinus) in comparison to water quality and metal concentration along the Vaal River, South Africa: Antropogenic activities have a negative effect on the water quality of the Vaal River in South Africa. Water quality parameters and metal concentrations in the water of the Vaal River were determined and compared to the prevalence and the mean intensity of the parasite Lamproglena clariae on the African sharptooth catfish. Increasing metal concentrations correlated with lower water quality parameters and parasite loads.

Die Vaalrivier maak 'n belangrike bydrae tot die ekonomie en ekologie van Suid-Afrika. Verskeie antropogeniese aktiwiteite en selfs natuurlike prosesse kan besoedeling veroorsaak, wat'n nadelige effek op die ekologie van dié varswatersisteem kan uitoefen. Bio-akkumulering van verskeie metale kom as gevolg van besoedeling in akwatiese sisteme voor en dit kan tot gesondheidsrisiko's lei vir alle organismes wat op die waterbron staatmaak. Tydens hierdie studie is waterkwaliteitparameters en metaalkonsentrasies in die rivier se water gemeet en vergelyk met die teenwoordigheid van die parasiet Lamproglena clariae op die skerptandbaber, Clarias gariepinus. Gedurende Maart 2017 was minstens 10 Clarias gariepinus-visse met kieunette, elektronarkose of deur middel van lynhengel by die volgende ses plekke in die Vaalrivier ingesamel: Onder-Grootdraaidam, Vaaldam, Vaalrivier Barragekeerwal, Bloemhofdam, Vaalhartsdam en Douglaskeerwal. Al die visse is vir die aanwesigheid van L. clariae ondersoek. Waterkwaliteitparameters (geleiding, suurstofversadiging, persentasie opgeloste suurstof, totale opgeloste vastestowwe, saliniteit, $\mathrm{pH}$ en temperatuur) is met 'n YSI 556 Multi-Probemeter gemeet. Daarna is watermonsters geanaliseer om metaalkonsentrasies te bepaal deur induktiefgekoppelde massaspektrometrie. Die aanwesigheid en intensiteit van parasiete is vir elke plek waar meting gedoen is, bepaal. Daar is gevind dat metaalkonsentrasies daartoe gelei het dat die waterkwaliteit stroomaf afgeneem het. Die Vaalrivier-Barragekeerwal (Bo-Vaal) en Douglaskeerwal (Laer-Vaal) het swakker waterkwaliteit ten opsigte van konduktiwiteit, totale opgeloste vastestowwe en saliniteit getoon. Die meeste L. clariae is by die Grootdraaidam (Bo-Vaal) gevind, gevolg deur die Bloemhofdam (Middel-Vaal). Areas met ' $n$ hoë intensiteit antropogeniese aktiwiteite soos byvoorbeeld myne is geïdentifiseer as die areas waar die minste parasiete voorgekom het. Daarom kan besoedeling wat deur hierdie aktiwiteite veroorsaak word, verbind word met 'n noemenswaardige effek op die teenwoordigheid en intensiteit van L. clariae op C. gariepinus in die Vaalrivier.

Nota: 'n Seleksie van referaatopsommings: Studentesimposium in die Natuurwetenskappe, 25-26 Oktober 2018, SA Akademiegebou, Pretoria, Suid-Afrika. Gasredakteurs: Prof Rudi Pretorius (Departement Geografie, Universiteit van Suid-Afrika); Prof Chris Swanepoel (Departement Besluitkunde, Universiteit van Suid-Afrika); Me Andrea Lombard (Departement Geografie, Universiteit van Suid-Afrika) 